\title{
The Relationship between Organizational Citizenship Behavior and Counterproductive Work Behavior
}

\author{
Hafidz, S. W. M. ${ }^{1}$, Hoesni, S. M. ${ }^{1} \&$ Fatimah, O. ${ }^{1}$ \\ ${ }^{1}$ School of Psychology and Human Development, Faculty of Social Sciences and Humanities, Universiti \\ Kebangsaan Malaysia, Bangi, Malaysia \\ Correspondence: Hafidz, S. W. M., School of Psychology and Human Development, Faculty of Social Sciences \\ and Humanities, Universiti Kebangsaan Malaysia, 43600 UKM Bangi, Selangor, Malaysia. Tel: 60-3-8921-5209. \\ E-mail:waheeda@ukm.my
}

Received: June 4, 2012 Accepted: June 16, $2012 \quad$ Published: July 16, 2012

doi:10.5539/ass.v8n9p32

URL: http://dx.doi.org/10.5539/ass.v8n9p32

\begin{abstract}
Job performance is the most researched concept studied in industrial and organizational psychology, with the emphasis being on organizational citizenship behavior (OCB) and counterproductive work behavior (CWB) as two dimensions of it. The relationship between these two dimensions of job performance are unclear, hence the objective of the current study was to examine the relationship between organizational citizenship behavior and counterproductive work behavior. A total of 267 students studying psychology were given a questionnaire that measured organizational citizenship behavior and counterproductive work behavior (most have had part-time work experience). Correlational analysis found OCB and CWB to have only a moderate negative correlation which suggests OCB and CWB are two separate but related constructs. It was also found that females and longer-tenured individuals tend to show more OCB but no difference was found for CWB. The findings showed that individuals can engage in $\mathrm{OCB}$ and $\mathrm{CWB}$ at the same time, which necessitates organizations to find a way to encourage their employees to engage in OCB and not in CWB.
\end{abstract}

Keywords: organizational citizenship behavior, counterproductive work behavior, job performance

\section{Introduction}

Job performance has been a very much researched area in industrial and organizational psychology due to its importance to an organization. An organization's success very much depends on the performance of its employees, thus good job performance is something organizations try to foster. Job performance can be defined as scalable actions, behavior and outcomes that employees engage in or bring about that are linked with and contribute to organizational goals (Viswesvaran and Ones, 2000). Rotundo and Sackett (2002) have grouped job performance around three broad dimensions: task performance, organizational citizenship behavior (OCB) and counterproductive work behavior (CWB). This study will focus on the last two dimensions of job performance due to the force of impact it has on an organization.

Research in the area of job performance has previously focused on organizational citizenship behavior (OCB). Organ (1997) defined OCB as those behaviors that contribute to the maintenance and enhancement of the social and psychological context that supports task performance. This definition clearly shows that these behaviors are not required of the job, but are performed by the employee in order to enhance the environment in the organization, and contribute indirectly to the effectiveness of the organization.

Podsakoff et al. (1997) stated that over time and persons, citizenship behaviors become important because it helps to facilitate the accomplishments of organizational goals and thus enhances organizational performance. Murphy et al. (2002) then reiterated that OCB is vital to the survival of an organization, in the sense that OCB can maximize the efficiency and promote effective functioning of an organization.

There have been many attempts at categorizing OCB. Bateman and Organ (1983) suggested that OCB can be divided into items that measure cooperation, altruism, compliance, punctuality, housecleaning, protecting company property, conscientiously following company rules, and dependability; and these items were considered to be a composite measure of OCB. Smith et al. (1983) suggested OCB be divided into altruism and generalized compliance. Williams and Anderson (1991) suggested OCB to be divided into behavior that benefits 
the organization (OCB-O) and behavior that benefits specific individual but indirectly also benefits the organization (OCB-I). Podsakoff et al. (2000) based on a critical review of the literature identified seven dimensions of OCB: helping behavior, sportsmanship, organizational loyalty, organizational compliance, individual initiative, civic virtue, and self-development.

Organ (1988) suggested five factors of OCB, but this is mainly based on empirical evidence that is obtained from several other studies (i.e. Bateman and Organ, 1983; Smith et al., 1983). The five dimensions of OCB identified by Organ are altruism, civic virtue, conscientiousness, courtesy, and sportsmanship. Podsakoff et al. (1990) developed a scale to measure OCB based on the dimensions suggested by Organ. LePine et al. (2002) in their review and meta-analysis stated that the scales developed by Podsakoff et al. (1990) has been used in numerous studies, thus perhaps making it the most utilized scale of OCB.

More recently, researchers have started to explore the other dimension of job performance that seems to be on the opposite of OCB. Sackett and DeVore (2001) defined counterproductive work behavior (CWB) as any intentional behavior on the part of an organization member viewed by the organization as contrary to its legitimate interests. It is important to note that behaviors that are accidental cannot be considered as counterproductive, as it happened without the individual intending for it to happen.

Harper (1990) found that an estimate of 33-75\% of employees have engaged in CWB at some point during the time that they serve in an organization. In addition, the outcome of employee deviance and delinquency accounted for between $\$ 6$ billion to $\$ 200$ billion of organizational loss annually (Murphy, 1993).

Research on CWB has been done differently, with some research looking at specific facets of CWB such as absence (e.g., Dalton and Mesch, 1991), aggression (e.g., Douglas and Martinko, 2001; Fox and Spector, 1999), and theft (e.g., Greenberg, 1990). At the same time, studies on CWB also looked at these behaviors collectively and this will be explored more below. Hence, Spector et al. (2006) have suggested that CWB be summed up as a hierarchical model. This model suggests that CWB be looked at as an overall counterproductive construct, with other suggested dimensionality being organized underneath this.

Similar to OCB, many researches has attempted to deal with the issue of looking at the dimensionality of CWB. One of the earliest works on CWB by Hollinger and Clark (1982) suggested CWB be divided into production deviance and property deviance. Robinson and Bennett (1995) went on to suggest that deviant behaviors cannot only be seen using the two dimensions of 'minor versus serious deviance' and 'interpersonal versus organizational deviance', but can also be classified into four categories of property deviance, production deviance, political deviance, and personal aggression. In 2000, Bennett and Robinson revisited their categorization and suggested that CWB be categorized into two general dimensions of interpersonal deviance and organizational deviance. Gruys and Sackett (2003) proposed a more comprehensive model that comprises of eleven categories of CWB: theft and related behavior, destruction of property, misuse of information, misuse of time and resources, unsafe behavior, poor attendance, poor quality work, alcohol use, drug use, inappropriate verbal actions, and inappropriate physical actions. Spector et al. (2006) suggested that CWB be looked at as having five categories of abuse, theft, withdrawal, production deviance, and sabotage. Since Gruys and Sackett's model seems to be the most comprehensive, the current study will be using this model for the data collection and analysis.

Subsequently, many studies have been conducted in an attempt to establish the relationship between CWB and $\mathrm{OCB}$, especially since both of these are said to be dimensions of job performance. However, the findings regarding the relationship between OCB and CWB have been contradictory. On one hand, OCB and CWB are said to be the extremes on a single continuum; and this would be reflected by a strong negative correlation between them. If this is the case, then it would suggest that that if an individual engages in OCB, s/he will not engage in CWB or vice versa. Studies by Bukhari and Ali (2009) and Sackett (2002) supported this notion, with the correlations being -0.74 and -0.60 respectively. On the other hand, it has been suggested that OCB and CWB are two separate constructs, and this would be reflected by a weaker correlation between them. This would suggest that an individual could engage in both OCB and CWB at the same time, or not engage in both. And studies by Dalal (2005), Kelloway et al. (2002), O'Brien and Allen (2008), and Sackett et al. (2006) have supported the notion that $\mathrm{OCB}$ and CWB are separate constructs (correlations ranging from -0.20 to -0.39 ) and that it is indeed possible to engage in both types of behavior at any one time.

Thus, it is clear that the relationship between OCB and CWB have not been strongly established. Therefore, the objectives of this study are:

1) to examine the relationship between OCB and CWB (OCB and CWB as a whole and also by looking at facets of each construct). 
2) to examine whether gender and tenure affects OCB and CWB.

\section{Method and Materials}

A survey was conducted to collect the data for this research. The participants were recruited using the University of Melbourne's Department of Psychology's Research Participation Pool (RPP); as well as getting students undertaking a third-year subject at the above said department to participate. The sample consisted of 72 males and 194 females with an age range of $17-52$ years $(\mathrm{M}=21.29, \mathrm{SD}=3.94)$. The participants were also asked to state their full-time and part-time work experience (in months worked). The part-time work experience ranged from never worked at all to having 120 months $(\mathrm{M}=37.18, \mathrm{SD}=26.9)$ experience whereas the full-time experience ranged from 0 months to 420 months $(\mathrm{M}=8.36, \mathrm{SD}=37.09)$. The questionnaire consisted of three parts: demographic information, a scale to measure OCB, and a scale to measure CWB. Data collected were analyzed using t-tests and Pearson correlation. Description of the questionnaire is as follows:

1). Organizational Citizenship Behavior (OCB): This 24-item scale was developed by Podsakoff et al. (1990). There are five dimensions in the scale: altruism, conscientiousness, sportsmanship, courtesy and civic virtue. The scale for conscientiousness, sportsmanship, courtesy, and altruism has five items; but civic virtue has four items. Only five items are negatively keyed $(2,7,12,17,22)$. Responses to the items are based on a six-point Likert scale. High scores indicate high organizational citizenship behavior and low scores indicate low organizational citizenship behavior. For each dimension a score will be obtained (the mean of the items in the scale) and the overall mean will be considered as overall score for general organizational citizenship behavior. Podsakoff et al. reported internal consistency reliabilities for each dimension that ranged from 0.70 for civic virtue to 0.85 for sportsmanship, courtesy, and altruism. The current study found the internal consistency reliability ranged from 0.50 (conscientiousness) to 0.80 (altruism).

2). Counterproductive Work Behavior (CWB): An 84-item questionnaire was used in this study to measure counterproductive work behavior. The items in this section are mostly based on the questionnaire used by Gruys and Sackett (2003), but some items were also added. The original questionnaire contained 63 items, and so for the purpose of analysis only these items will be included. Respondents were asked to rate the items using a five-point Likert scale. Again, similar to the OCB scale, for each dimension a score will be obtained (the mean of the items in the scale) and the overall mean will be considered as overall score of general CWB. High scores indicate higher acceptability of the counterproductive behaviors (high counterproductive work behavior) and lower scores indicate low acceptability of the behaviors (low counterproductive work behavior). The current study found the internal consistency reliability to range from 0.61 (alcohol use) to 0.89 (misuse of time and resources); with only two dimensions reporting an alpha value of smaller than 0.70 .

\section{Results and Discussion}

Results of Pearson correlation as seen in Table 1 shows that there was a significant negative relationship between CWB (and all of its dimensions) and OCB (see Table 1). Results of Pearson correlation as seen in Table 2 shows that there was a significant negative relationship between OCB (and four of its dimensions) and CWB (see Table 2) Only sportsmanship was found not to be significantly related to general CWB, but the correlation found was also negative.

Table 1. Pearson correlation analysis between CWB (and its dimensions) and OCB

\begin{tabular}{ll}
\cline { 2 - 2 } Variables & General OCB \\
\cline { 2 - 3 } Theft and related behaviour & $-0.297^{* *}$ \\
Destruction of property & $-0.233^{* *}$ \\
Misuse of information & $-0.293^{* *}$ \\
Misuse of time and resources & $-0.190^{* *}$ \\
Unsafe behaviour & $-0.137^{*}$ \\
Poor attendance & $-0.235^{* *}$ \\
Poor quality work & $-0.345^{* *}$ \\
Alcohol use & $-0.211^{* *}$ \\
Drug use & $-0.144^{*}$ \\
Inappropriate verbal actions & $-0.288^{* *}$ \\
Inappropriate physical actions & $-0.225^{* *}$ \\
General CWB & $-0.332^{* *}$ \\
\hline
\end{tabular}

$* * \mathrm{p}<0.05 ; * \mathrm{p}<0.01$ 
Table 2. Pearson correlation analysis between OCB (and its dimensions) and CWB

\begin{tabular}{ll}
\hline Variables & General CWB \\
\hline Altruism & $-0.182^{*}$ \\
Civic virtue & $-0.328^{*}$ \\
Conscientiousness & $-0.307^{*}$ \\
Courtesy & $-0.229^{*}$ \\
Sportsmanship & -0.085 \\
General OCB & $-0.332^{*}$ \\
\hline
\end{tabular}

$* \mathrm{p}<0.05$

This result clearly shows a negative relationship between OCB and CWB, but also that the magnitude of the relationship is relatively small (ranging from -0.137 to -0.345 ). The research finding is consistent with the findings of Dalal (2005), Kelloway et al. (2002), O'Brien and Allen (2008), and Sackett et al. (2006); where all of these researches found only a moderate negative relationship between the two constructs. The relatively small correlation value suggests that the two constructs are indeed related albeit the relationship being moderate at most; but it also suggests that the two constructs are separate and not located on a single continuum. This goes on to suggest that it is possible for an individual to engage in both types of behaviour at any one time. Research by Kelloway et al. (2002), O'Brien and Allen (2008), and Sackett et al. (2006) also used confirmatory factor analysis to compare different models (to be used as an indicator of the relationship between OCB and CWB), and all concluded OCB and CWB as separate constructs based on the best-fitting model. The current study looked at CWB using a bigger number of dimensions of CWB, whereas many past researches have only used the two-dimensional solution of interpersonal versus organizational-directed deviance.

It is probable that an individual will engage in both types of behavior at the same time, as it has been suggested that generally $\mathrm{OCB}$ and $\mathrm{CWB}$ happens due to individual, organizational, and situational factors. Individual factors tend to be more stable, whereas situational factors tend to fluctuate. For example, how one feels one week could be very different to how one feels the week after. Situational factors such as organizational climate and culture, and also perception of justice/injustice-fairness are more fluid, thus, could contribute to understanding why an individual could engage in both behaviors at one time. As an example, it is possible that an individual is satisfied with some aspects of their job and at the same time feel some dissatisfaction towards other aspects of their job; and so this contradictory feelings could instigate both types of behavior. Spector and Fox (2010) proposed five situations that could cause OCB and CWB to exist in parallel: under-stimulation at work, co-worker lack of performance, organizational constraints, lack of expected rewards for OCB, and unjustified acts of CWB.

T-tests were also conducted to see if gender and tenure has any bearings on OCB and CWB, and the results are shown in Table 3 and 4. Interestingly, it was found that gender and tenure has an effect on OCB only, and not on CWB. It was found that females tend to engage in higher OCB, t $(263)=-3.01, p<0.05$ and longer tenured individuals also tend to engage in more OCB, $\mathrm{t}(263)=-2.82, \mathrm{p}<0.05$. In the current study, longer tenure is classified as individuals who have worked for more than five years. It is not surprising to learn that longer-tenured individuals engage in more $\mathrm{OCB}$, as these individuals perhaps feel more of a sense of belonging to the organization as compared to 'newer' employees. This could also be due to these individuals having a better social network and thus better relationship with other employees in the organization. On the other hand, tenure does not have any effect on CWB; and this can perhaps be explained by thinking about the nature of CWB as opposed to OCB. OCB is a positive feeling that is nurtured towards a company, and hence an individual will have higher OCB the longer they have been in an organization. For CWB, the feelings of dissatisfaction can easily arise, and this one instance of dissatisfaction or unhappiness could cause CWB, irrespective of how long the individual has worked in the organization. (see Table 3 and Table 4).

Table 3. t-test analysis for OCB and CWB based on gender

\begin{tabular}{clccccc}
\hline Domain & Gender & $\mathrm{N}$ & Mean & SD & $\mathrm{df}$ & $\mathrm{t}$ \\
\hline OCB & Male & 71 & 4.52 & 0.46 & 263 & $-3.00^{*}$ \\
& Female & 194 & 4.70 & 0.42 & & \\
CWB & Male & 71 & 1.69 & 0.36 & 263 & -1.11 \\
& Female & 194 & 1.69 & 0.39 & & \\
\hline
\end{tabular}

${ }^{*} \mathrm{p}<0.05$ 
Table 4. t-test analysis for OCB and CWB based on tenure

\begin{tabular}{clccccc}
\hline Domain & Tenure & $\mathrm{N}$ & Mean & SD & df & $\mathrm{t}$ \\
\hline OCB & Short & 212 & 4.62 & 0.44 & 263 & $-2.82^{*}$ \\
& Long & 53 & 4.80 & 0.37 & & \\
CWB & Short & 212 & 1.70 & 0.39 & 263 & 0.62 \\
& Long & 53 & 1.66 & 0.36 & & \\
\hline
\end{tabular}

*p $<0.05$

\section{Conclusion}

Based on results of the current study, it can be concluded that OCB and CWB are related but separate constructs. This means that an individual could very well engage in both types of behavior at the same time. Organizations would need to find a way to encourage their employees to engage in $\mathrm{OCB}$ and at the same time to find ways to stop their employees from engaging in CWB. Organizations could perhaps put in place a mentoring program where 'older' employees can help 'newer' employees. Organizations should also find ways to curb CWB, as it brings no benefit to the organization, but rather cripples the organization.

\section{References}

Bateman, T. S., \& Organ, D. W. (1983). Job satisfaction and the good soldier: The relationship between affect and empoyee 'citizenship'. Academy of Management Journal, 26(4), 587-595. http://dx.doi.org/10.2307/255908

Bennet, R. J., \& Robinson, S. L. (2000). Development of a measure of workplace deviance. Journal of Applied Psychology, 85(3), 349-360. http://dx.doi.org/10.1037//0021-9010.85.3.349

Bukhari, Z., \& Ali, U. (2009). Relationship between organizational citizenship behaviour and counterproductive work behaviour in the geographical context of Pakistan. International Journal of Business and Management, 4, 85-92.

Dalal, R. S. (2005). A meta-analysis of the relationship between organizational citizenship behaviour and counterproductive work behaviour. Journal of Applied Psychology, 90(6), 1241-1255. http://dx.doi.org/10.1037/0021-9010.90.6.1241

Dalton, D. R., \& Mesch, D. J. (1991). On the extent and reduction of avoidable absenteeism: An assessment of absence policy provisions. Journal of Applied Psychology, 76(6), 810-817. http://dx.doi.org/10.1037/0021-9010.76.6.810

Douglas, S. C., \& Martinko, M. J. (2001). Exploring the role of individual differences in the prediction of workplace aggression. Journal of Applied Psychology, 86(4), 547-559. http://dx.doi.org/10.1037/0021-9010.86.4.547

Fox, S., \& Spector, P. E. (1999). A model of work frustration-aggression. Journal of Organizational Behaviour, 20, 915-930. http://dx.doi.org/10.1002/1099-1379.20.6.915

Greenberg, J. (1990). Employee theft as a reaction to underpayment inequity: The hidden cost of pay cut. Journal of Applied Psychology, 75(6), 561-568. http://dx.doi.org/10.1037/0021-9010.75.6.561

Gruys, M. L., \& Sackett, P. R. (2003). Investigating the dimensionality of counterproductive work behaviour. International Journal of Selection and Assessment, 11(1), 30-42. http://dx.doi.org/10.1111/1468-2389.00224

Harper, D. (1990). Spotlight abuse-save profits. Industrial Distribution, 79, 47-51.

Hollinger, R. C., \& Clark, J. P. (1982). Formal and informal social controls of employee deviance. The Sociological Quarterly, 23, 333-343. http://dx.doi.org/10.1111/j.1533-8525.1982.01016

Kelloway, E. K., Loughlin, C., Barling, J., \& Nault, A. (2002). Self-reported counterproductive behaviours and organizational citizenship behaviours: Separate but related constructs. International Journal of Selection and Assessment, 10(1-2), 143-151. http://dx.doi.org/10.1111/1468-2389.00201

LePine, J. A., Erez, A., \& Johnson, D. E. (2002). The nature and dimensionality of organizational citizenship behaviour: A critical review and meta-analysis. Journal of Applied Psychology, 87(1), 52-65. http://dx.doi.org/10.1037//0021-9010.87.1.52 
Murphy, G., Athanasou, J., \& King, N. (2002). Job satisfaction and organisational citizenship behaviour: A study of Australian human-service professionals. Journal of Managerial Psychology, 17(4), 287-297. http://dx.doi.org/10.1108/02683940210428092

Murphy, K. R. (1993). Honesty in the workplace. Belmont, CA: Brooks/Cole.

O'Brien, K. E., \& Allen, T. D. (2008). The relative importance of correlates of organizational citizenship behaviour and counterproductive work behaviour using multiple sources of data. Human Performance, 21, 62-88. http://dx.doi.org/10.1080/08959280701522189

Organ, D. W. (1988). Organizational citizenship behaviour: The good soldier syndrome. Lexington, MA: Lexington Books.

Organ, D. W. (1997). Organizational citizenship behaviour: It's construct clean-up time. Human Performance, 10(2), 85-97. http://dx.doi.org/10.1207/s15327043hup1002_2

Podsakoff, P. M., Ahearne, M., \& Mackenzie, S. B. (1997). Organisational citizenship behaviour and the quantity and quality of work group perfomance. Journal of Applied Psychology, 82(2), 262-270. http://dx.doi.org/10.1037/0021-9010.82.2.262

Podsakoff, P. M., MacKenzie, S. B., Moorman, R. H., \& Fetter, R. (1990). Transformational leader behaviours and their effects on followers' trust in leader, satisfaction, and organizational citizenship behaviours. Leadership Quarterly, 1(2), 107-142. http://dx.doi.org/10.1016/1048-9843(90)90009-7

Podsakoff, P. M., MacKenzie, S. B., Paine, J. B., \& Bachrach, D. G. (2000). Organizational citizenship behaviours: A critical review of the theoretical and empirical literature and suggestions for future research. Journal of Management, 26(3), 513-563. http://dx.doi.org/10.1177/014920630002600307

Robinson, S. L., \& Bennett, R. J. (1995). A typology of deviant workplace behaviours: A multidimensional scaling study. Academy of Management Journal, 38(2), 555-572. http://dx.doi.org/10.2307/256693

Rotundo, M., \& Sackett, P. R. (2002). The relative importance of task, citizenship, and counterproductive performance to global ratings of job performance: A policy capturing approach. Journal of Applied Psychology, 87(1), 66-80. http://dx.doi.org/10.1037/0021-9010.87.1.66

Sackett, P. R. (2002). The structure of counterproductive work behaviours: Dimensionality and relationships with facets of job performance. International Journal of Selection and Assessment, 10(1-2), 5-11. http://dx.doi.org/10.1111/1468-2389.00189

Sackett, P. R., \& DeVore, C. J. (2001). Counterproductive behaviours at work. In N. Anderson, D. S. Ones, H. K. Sinangil \& C. Viswesvaran (Eds.), Handbook of Industrial, Work and Organizational Psychology (Vol. 1, pp. 145-164). London, UK: Sage.

Sackett, P. R., Berry, C. M., Wiemann, S. A., \& Laczo, R. M. (2006). Citizenship and counterproductive behaviour: Clarifying relations between the two domains. Human Performance, 19(4), 441-464. http://dx.doi.org/10.1207/s15327043hup1904_7

Smith, C. N., Organ, D. W., \& Near, J. P. (1983). Organizational citizenship behaviour: Its nature and antecedents. Journal of Applied Psychology, 68(4), 653-663. http://dx.doi.org/10.1037/0021-9010.68.4.653

Spector, P. E., \& Fox, S. (2010). Counterproductive work behaviour and organizational citizenship behaviour: Are they opposite forms of active behaviour? Applied Psychology: An International Review, 59(1), 21-39. http://dx.doi.org/10.1111/j.1464-0597.2009.00414

Spector, P. E., Fox, S., Penney, L. M., Bruursema, K., Goh, A., \& Kessler, S. (2006). A dimensionality of counterproductivity: Are all counterproductive behaviours created equal? Journal of Vocational Behaviour, 68(2006), 446-460. http://dx.doi.org/10.1016/j.jvb.2005.10.005

Viswesvaran, C., \& Ones, D. S. (2000). Perspectives on models of job performance. International Journal of Selection and Assessment, 8, 216-227. http://dx.doi.org/10.1111/1468-2389.00151

Williams, L. J., \& Anderson, S. E. (1991). Job satisfaction and organizational commitment as predictors of organizational citizenship and in-role behaviours. Journal of Management, 17, 601-617. http://dx.doi.org/10.1177/014920639101700305 